\title{
Strategi Kreatif Menulis Advertorial Menggunakan Microsoft Word
}

\author{
Ratna Kartika Sari ${ }^{1}$ \\ Fakultas Komunikasi dan Bahasa, Universitas Bina Sarana Informatika, \\ ratna.rtk@bsi.ac.id \\ Iin Soraya ${ }^{2}$ \\ Fakultas Komunikasi dan Bahasa, Universitas Bina Sarana Informatika, \\ iin.ina@bsi.ac.id
}

\begin{abstract}
Abstrak
Advertorial merupakan jenis iklan yang dikemas dalam gaya jurnalistik dan ditulis dalam bentuk editorial atau artikel yang memuat informasi mengenai kegiatan perusahaan atau review keunggulan sebuah produk disertai fakta empiris dan informasi yang berguna. Tujuan penulisan iklan ini adalah untuk menyatukan berita dan pesan komersil, sehingga menjadikan alat pemasaran ini bersifat lebih kredibel dan efektif. Advertorial dapat digunakan untuk melakukan promosi aktivitas perusahaan maupun promosi produk, yang pada dasarnya berusaha menggiring pembaca untuk menyakini bahwa perusahaan atau produk tersebut memberikan manfaat, serta menjadi solusi bagi permasalahan yang mereka hadapi. Pelatihan penulisan advertorial yang diselenggarakan Fakultas Komunikasi dan Bahasa Universitas BSI bertujuan menambah pengetahuan dan ketrampilan peserta di bidang penulisan, khususnya advertorial. Hal ini akan mempermudah dan memperlancar urusan kedinasan maupun promosi produk-produk bagi yang mengelola usaha sendiri. Berdasarkan evaluasi terungkap, bahwa sebagian besar peserta belum pernah menggunakan komputer dalam kegiatan penulisan, baik dalam menulis informasi yang dipasang di papan pengumuman, surat menyurat, maupun menulis pesan promosi untuk produk-produk yang mereka jual. Peserta juga belum pernah secara khusus mengikuti pelatihan penulisan, baik untuk keperluan pribadi maupun kedinasan. Selain itu, peserta juga tidak mengenal advertorial sebagai salah satu sarana promosi yang bertujuan sama seperti iklan konvensional yang biasa ditayangkan di media massa. Namun, setelah mengikuti pelatihan, para peserta kini mampu melakukan penulisan menggunakan Microsoft Word, dan memadukannya dengan gambar-gambar yang tersedia di aplikasi tersebut. Selanjutnya, diharapkan peserta akan terus menerapkan dan meningkatkan ketrampilan menulis yang dimiliki agar dapat menghasilkan tulisan yang lebih menarik dan bervariasi, baik yang bersifat informatif maupun persuasif.
\end{abstract}

Kata Kunci: Strategi Kreatif, Iklan, Advertorial

\begin{abstract}
An advertorial is a type of advertising in a journalistic style and written in an editorial or an article form contains information about company activities or reviews of qualities of a product
\end{abstract}


along with empirical facts and beneficial information. Writing an advertorial aims to integrate news and commercial messages with the result that this marketing tool will be more credible and effective. An advertorial can be used to promote activities of a company as well as products, which basically attempts to lead readers to assume that the company or products provide benefits and a solution to the problems they face. An advertorial writing training organized by the Faculty of Communication and Language of BSI University intended to enhance knowledge and skills of participants in writing, especially an advertorial. This will simplify and accelerate the official charges and promoting products for those who manage their own businesses. Based on the evaluation, it was revealed that most participants have never used computers in writing information posted on bulletin boards, correspondence, as well as promotional messages for the products they sold. Participants also have never specifically participated in any writing training, either for personal and official purposes. Another fact is that participants are also unfamiliar with advertorial as a means of promotion that has the same goal as conventional advertising which usually broadcast in mass media. However, after the training, participants are now able to do the writing applied on Microsoft Word, then integrate it with images/figures on the application. Furthermore, it is expected that participants will keep on implementing and enhancing their writing skills to write more interesting and varied writings, both informative and persuasive.

Keywords : Creative Strategy, Advertising, Advertorial

\section{Pendahuluan}

Penulisan iklan merupakan salah satu strategi pemasaran yang memanfaatkan media massa sebagai sarana penyampaiannya. Kegiatan ini telah lama dilakukan para pemasar yang secara persuasif berusaha menarik minat beli publik terhadap suatu produk, baik barang maupun jasa. Iklan yang biasa ditampilkan di media massa biasanya berupa iklan yang langsung berisi pesan persuasif dengan dilengkapi gambar produk yang ditawarkan. Namun, kini mulai bermunculan jenis iklan lain yang bertujuan sama, hanya saja dalam bentuk dan format penulisan yang berbeda dengan iklan pada umumnya, yaitu advertorial.

Advertorial merupakan bentuk periklanan yang disajikan dengan gaya jurnalistik. Advertorial berasal dari dua kata dalam bahasa Inggris, yaitu Advertising dan Editorial. Advertising merupakan penyajian materi secara persuasif kepada publik melalui media massa dengan tujuan untuk mempromosikan barang atau jasa. Sementara editorial merupakan pernyataan tentang opini yang merupakan sikap resmi dari redaksi. (Maulina Rishna, 2019)

Rendra Widyatama berpendapat, bahwa advertorial mempunyai ukuran luas sebagaimana ukuran display, hanya saja teknik penyampaian pesan lebih diarahkan pada bentuk seperti sebuah berita, dengan naskah yang panjang. (Partawan, Km. Sugi, I. B. Putrayasa, 2014)

Senada dengan pendapat tersebut, John E. Kennedy dan R. Dermawan Soemanagara dalam (Negara, 2016) menegaskan, bahwa berbeda dengan iklan, advertorial merupakan iklan yang terlihat seperti berita, dibaca seperti berita, tetapi sering dibeli dan dikendalikan oleh pengiklan. Salah satu tujuan dari advertorial adalah 
menjadikan berita dengan pesan komersil (berbau publikasi) menjadi satu sehingga menjadikan alat pemasaran ini menjadi "kendaraan pemasaran" yang bersifat lebih kredibel dan efektif. Advertorial telah mengambil fungsi dari iklan dan peran dari berita yang kemudian dileburkan dan diolah menjadi bentuk penulisan padat, mengandung informasi $5 \mathrm{~W}+1 \mathrm{H}$.

Advertorial dibuat dalam bentuk tulisan editorial atau artikel yang nantinya akan dimuat di majalah, surat kabar, jurnal, dan website. Editorial atau artikel yang dibuat berisi informasi mengenai kegiatan perusahaan atau review keunggulan sebuah produk disertai dengan fakta empiris dan informasi yang berguna. Dengan penggunaan iklan seperti ini, pembaca akan merasa menerima informasi biasa layaknya membaca artikel, padahal yang dibacanya adalah iklan terselubung. Pesan iklan disampaikan secara halus dan seringkali tidak disadari pembaca. (Warni, 2015) Penulisan advertorial yang mirip dengan penulisan berita membuat masyarakat berpikir bahwa yang menulis atau menyampaikan pesan tersebut adalah sumber terpercaya yang tidak memiliki kepentingan komersial terhadap produk yang bersangkutan. Akibatnya, tingkat kredibilitas informasinyapun lebih tinggi daripada iklan. (Primadini, 2016)

Dalam advertorial, terdapat dua fokus promosi yang bisa dikembangkan, yaitu:

1. Promosi aktivitas perusahaan, seperti aktivitas Pengabdian Masyarakat atau bahkan acara gathering yang digelar. Hal ini dilakukan untuk menunjukkan intensitas perusahaan dalam menjalankan fungsi pengabdian masyarakat atau bahkan untuk menunjukkan seberapa banyak klien atau nasabah dari perusahaan tersebut.

2. Promosi produk, seperti informasi mengenai khasiat tertentu dari kandungan produk, masalah yang sering muncul di masyarakat dan teratasi berkat produk tersebut, atau masih banyak lagi. Secara langsung, iklan ini menggiring pembaca untuk menganggap bahwa produk tersebut memang berkualitas, berkhasiat dan menjadi solusi terbaik. (Maulina Rishna, 2019)

Kedua jenis promosi tersebut dibuat pada dasarnya untuk memberikan informasi kepada masyarakat mengenai aktifitas perusahaan maupun produk yang dihasilkan, sehingga masyarakat dapat mengenal, memahami secara detail, dan akhirnya tergerak untuk melakukan berbagai hal yang diharapkan pengiklan.

Dalam proses pembuatannya, penulis advertorial dituntut untuk tidak hanya memiliki bekal ketrampilan atau tehnik menulis yang baik, namun juga harus memiliki kreatifitas yang tinggi agar tulisan yang dibuat terasa hidup, menarik perhatian dan mampu diterima secara logika, serta membangkitkan kebutuhan untuk membeli produk yang ditawarkan. Strategi kreatif dalam menulis dan menyampaikan isi pesan perlu dirumuskan dan diterapkan.

Strategi kreatif merupakan upaya bagaimana agar suatu inti pesan dapat diterima dengan baik oleh sasaran. Salah satu pendekatan proses kreatif iklan dikembangkan oleh Graham Wallas, seorang Sosiolog Inggris yang menyatakan bahwa, proses kreatif itu akan melalui tahapan sebagai berikut :

1. Persiapan, yaitu kegiatan mengumpulkan informasi latar belakang yang diperlukan untuk memecahkan masalah melalui riset dan studi. 
2. Inkubasi, yaitu proses mengembangkan ide atau gagasan.

3. Iluminasi, yaitu upaya mencari pemecahan masalah.

4. Verifikasi, yaitu upaya memperbaiki ide atau gagasan dan menentukan jika ide atau gagasan tersebut merupakan solusi yang tepat. (Sugihantoro, 2010)

Semua tahapan tersebut harus dilalui sebagai sebuah proses penting untuk mencapai kesuksesan dalam menghasilkan karya positif dan dinilai kreatif. Membangkitkan kreatifitas dalam berkarya sering menjadi masalah besar yang harus dihadapi banyak pihak di berbagai bidang kehidupan. Kreatifitas manusia bersifat tidak terbatas, dapat melampaui apa yang selama ini dibayangkan banyak orang. Itulah sebabnya, dalam membangkitkan kreatifitas seseorang terkadang diperlukan adanya pendampingan dan pemantauan agar kreatifitas itu terarah dan tepat sasaran.

Ilmu dan pengetahuan menulis advertorial yang kreatif inilah yang ingin dibagikan oleh para staf pengajar Fakultas Komunikasi dan Bahasa Universitas BSI kepada ibuibu PKK di lingkungan RPTRA H. Ohyar, Pegangsaan Dua, Jakarta Utara melalui kegiatan Pengabdian Masyarakat (PM). Para ibu diyakini banyak memiliki kemampuan lebih yang selama ini belum terlihat oleh orang lain karena memang belum digunakan atau belum ada kesempatan yang tepat untuk mengeluarkan kemampuan itu. Padahal, jika digali lebih dalam dan dikeluarkan dalam bentuk pemikiran atau perbuatan yang nyata, bisa saja kemampuan itu akan sangat bermanfaat tidak hanya untuk diri sendiri atau keluarganya, namun juga bermanfaat bagi banyak orang di berbagai wilayah. Hal ini yang mendasari banyak kegiatan mengarah kepada para ibu sebagai sasaran utamanya, termasuk kegiatan PM staf pengajar Fakultas Komunikasi dan Bahasa Universitas BSI. Sedangkan materi yang akan diberikan dalam pelatihan itu adalah penulisan advertorial dengan menggunakan aplikasi Microsoft Word yang fokus utamanya mempromosikan suatu produk.

Tujuan utama yang ingin dicapai dari pelaksanaan kegiatan PM ini adalah agar ibuibu PKK di lingkungan RPTRA H. Ohyar, Pegangsaan Dua, Jakarta Utara mendapat kesempatan untuk menggali kemampuan ataupun mengasah ketrampilan menulis dengan menggunakan media elektronik komputer. Selama ini banyak diantara ibuibu PKK tersebut yang belum pernah menggunakan komputer untuk menulis, maka ini merupakan saat yang tepat bagi mereka untuk memulai mempelajari penulisan dengan menggunakan komputer. Melalui kegiatan pelatihan penulisan ini diharapkan ibu-ibu PKK akan memiliki kemampuan dalam membuat sendiri iklan advertorial yang kreatif dengan menggunakan aplikasi Microsoft Word yang kelak akan sangat bermanfaat sebagai media informasi di lingkungan RW.02 tempat tinggal mereka.

Ketrampilan penulisan advertorial ini juga sangat bermanfaat bagi ibu-ibu yang memiliki usaha atau bisnis karena dapat mempromosikan produk dagangannya melalui advertorial yang ditulis sendiri, sehingga tidak mengeluarkan biaya untuk membayar orang lain sebagai penulis naskahnya. Lebih dari itu, diharapkan para ibu tersebut dapat membagi ketrampilan penulisan advertorial yang telah dimiliki kepada orang lain, serta menyemangati mereka untuk maju dengan menambah pengetahuan dan ketrampilan di bidang penulisan. 
Kegiatan PM penulisan iklan advertorial yang terkelola dengan baik akan memberikan manfaat bagi semua pihak yang terlibat. Bagi para peserta, kegiatan ini jelas akan menambah ilmu dan pengetahuan di bidang periklanan. Rasa percaya diri dan kebanggaan sebagai perempuan, khususnya ibu rumah tangga juga akan meningkat seiring bertambahnya ketrampilan di bidang penulisan iklan dengan menggunakan komputer. Apalagi, selama ini diketahui bahwa ketrampilan seperti ini hanya dimiliki oleh orang-orang tertentu yang memiliki kesempatan belajar dan kemampuan finansial yang cukup untuk mempelajari tehnik penulisan advertorial, baik secara formal maupun non-formal.

Sedangkan manfaat kegiatan PM bagi pihak penyelenggara, yaitu para staf pengajar Fakultas Komunikasi dan Bahasa beserta lembaga yang menaunginya adalah memperoleh kesempatan untuk melaksanakan salah satu kewajiban seperti tertuang dalam Tri Dharma Perguruan Tinggi (Pengajaran, Pengabdian Masyarakat, dan Penelitian). Ilmu Komunikasi yang telah dimiliki oleh para staf pengajar juga dapat diterapkan secara nyata, yaitu dengan melakukan komunikasi dua arah dan membina hubungan baik dengan semua pihak yang terlibat, khususnya dengan para peserta dan pengelola RPTRA H. Ohyar Pegangsaan Dua, Jakarta Utara. Proses pembelajaran yang harus dikemas secara sederhana, namun menarik dengan menggunakan kata-kata dan istilah-istilah yang mudah dipahami seluruh peserta merupakan tantangan tersendiri bagi para staf pengajar dalam memahami karakteristik para peserta yang akan dibimbingnya. Universitas BSI juga merasakan manfaat kegiatan PM ini, yaitu dapat melaksanakan kewajiban sebagai lembaga pendidikan tinggi yang harus aktif berperan dalam meningkatkan wawasan dan pengetahuan seluruh komponen masyarakat, serta memberdayakan perempuan, khususnya kaum ibu yang diharapkan dapat menciptakan kehidupan keluarga yang lebih baik.

\section{Metode}

Penelitian ini merupakan penelitian kualitatif dengan metode deskriptif yang akan memberikan gambaran secara menyeluruh mengenai pelaksanaan Pelatihan Pembuatan Advertorial Menggunakan Microsoft Word. Data yang akan digunakan adalah data primer dan sekunder, yaitu data yang diperoleh berdasarkan hasil observasi di lapangan, wawancara dengan para pengelola RPTRA H. Ohyar, Pegangsaan Dua, Jakarta Utara, serta dilengkapi teori-teori atau kajian pustaka yang terkait dengan topik permasalahan penelitian.

Sedangkan metode yang akan diterapkan dalam kegiatan Pengabdian Masyarakat dengan sasaran ibu-ibu PKK di lingkungan RPTRA H. Ohyar itu sendiri adalah dalam bentuk ceramah (penyajian materi), diskusi, serta pelatihan atau praktek langsung penulisan advertorial menggunakan aplikasi Microsoft Word. Dalam pelatihan dan praktek secara langsung ini, semua peserta akan didampingi oleh para tutor yang membimbing dari awal hingga akhir kegiatan. Pendekatan secara komunikatif dua arah diterapkan sehingga para peserta dapat dengan leluasa, tanpa rasa sungkan, memberitahukan dan menanyakan kepada pembimbingnya saat mengalami kesulitan atau masalah dalam membuka dan menggunakan aplikasi Microsoft Word serta memulai menulis iklan advertorial di komputer masing-masing. 


\section{Hasil dan Pembahasan}

Pengabdian Masyarakat (PM) merupakan kegiatan wajib yang harus diselenggarakan dalam setiap semester oleh para staf pengajar Universitas BSI, termasuk staf pengajar Fakultas Komunikasi dan Bahasa. Kegiatan PM semester ini difokuskan pada pelatihan penulisan advertorial menggunakan Microsoft Word dengan peserta ibu-ibu PKK RPTRA H.Ohyar, Pegangsaan Dua, Jakarta Utara.

Pada dasarnya kegiatan Pengabdian Masyarakat ini dilaksanakan melalui beberapa tahap, antara lain :

\section{Persiapan}

Tahap ini menjadi tahap awal yang sangat menentukan keberlangsungan kegiatan PM yang dilaksanakan. Dapat dikatakan, bahwa tahap ini merupakan cermin dari keseluruhan pelaksanaan kegiatan PM, artinya, kesuksesan pelaksanaan kegiatan PM dapat diperkirakan akan terwujud sesuai yang diharapkan apabila tahap persiapan ini berjalan lancar dan lengkap, tidak ada satu komponenpun yang terlewatkan / terlupakan.

Tahap persiapan terdiri atas persiapan awal (perencanaan) dan persiapan akhir (menjelang dimulainya kegiatan). Dalam tahap perencanaan, semua pihak yang terlibat, terutama panitia penyelenggara kegiatan melakukan koordinasi, baik secara internal maupun eksternal. Koordinasi internal berlangsung diantara sesama individu penyelenggara, sedangkan koordinasi eksternal berlangsung diantara penyelenggara dengan pihak mitra, yaitu para pengelola RPTRA H. Ohyar, Pegangsaan Dua, Jakarta Utara. Komunikasi yang dibangun berkisar pada masalah kelengkapan personil dengan segala tanggungjawabnya, serta pengecekan kelengkapan peralatan dan materi yang akan digunakan dalam kegiatan PM. Disisi lain, komunikasi dengan mitra dilakukan untuk membahas jadwal dan agenda kegiatan, kesiapan tempat, perlengkapan pendukung, serta kesiapan para peserta. Survey lokasi dilakukan untuk memastikan ruang dan fasilitas yang tersedia untuk menggelar pelatihan dengan jumlah peserta yang dipastikan lebih dari 10 orang.

\section{Pelaksanaan}

Pelaksanaan kegiatan Pelatihan Penulisan Advertorial Menggunakan Microsoft Word dihadiri oleh para staf pengajar Fakultas Komunikasi dan Bahasa Universitas BSI serta pengelola dan para peserta yang merupakan ibu-ibu PKK di lingkungan RPTRA H. Ohyar, Pegangsaan Dua, Jakarta Utara. Acara pelatihan diawali dengan penyampaian kata sambutan oleh koordinator pengelola RPTRA H. Ohyar, yang pada dasarnya menyambut gembira diselenggarakannya kegiatan pelatihan ini, serta berharap agar kegiatan sejenis dapat diadakan secara rutin di waktu-waktu mendatang.

Kegiatan pelatihan penulisan advertorial dibagi dalam beberapa sesi, antara lain ceramah (penyajian materi), diskusi, dan praktek penulisan oleh peserta yang langsung dilakukan dengan menggunakan komputer. Dalam sesi Ceramah (penyajian materi), staf pengajar yang bertindak sebagai pembawa materi menjelaskan secara detail mengenai pengertian advertorial, cara kreatif dalam membuat advertorial menggunakan Microsoft Word, serta contoh advertorial yang 
sudah siap ditayangkan di media massa. Selain itu, dijelaskan pula mengenai Microsoft Word yang akan digunakan nanti beserta fungsi dan fasilitas yang tersedia dalam aplikasi tersebut. Semua materi ditulis dalam slide-slide yang menggunakan kalimat-kalimat sederhana disertai gambar-gambar yang menarik agar memudahkan peserta untuk memahami materi yang disampaikan. Selanjutnya, diadakan sesi Diskusi, dimana para peserta diberikan kesempatan untuk mengajukan pertanyaan jika masih ada materi yang belum dipahami. Sesi terakhir adalah sesi Praktek, yaitu saat dimana para peserta dapat melakukan penulisan advertorial di komputer masing-masing dengan berpedoman pada materi panduan yang telah disediakan oleh panitia dan dibagikan kepada para peserta. Pada sesi ini para peserta diminta untuk mengikuti arahan atau perintah yang diberikan pembawa materi, tentunya dengan dibantu oleh para tutor sebagai pembimbingnya. Diawali dengan cara memulai pengoperasian komputer, lalu membuka aplikasi Microsoft Word dan pengenalan tools yang tersedia dalam aplikasi tersebut, serta fungsi dan cara penggunaannya. Setelah itu, dilanjutkan dengan aktifitas pengetikan (mulai dari judul, headline, batang tubuh advertorial yang berisi informasi detail mengenai produk, dan kesimpulan sebagai penutup), lalu menentukan layout, serta terakhir adalah proses editing.
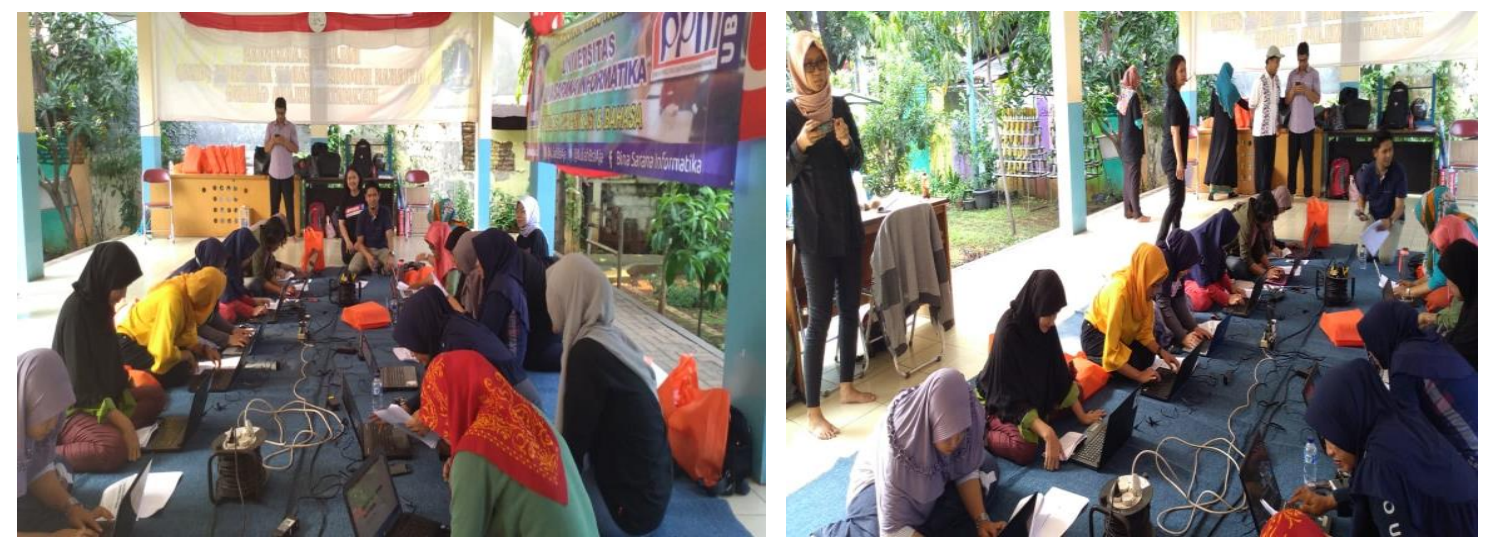

Gambar 1. Para peserta memulai sesi Praktek
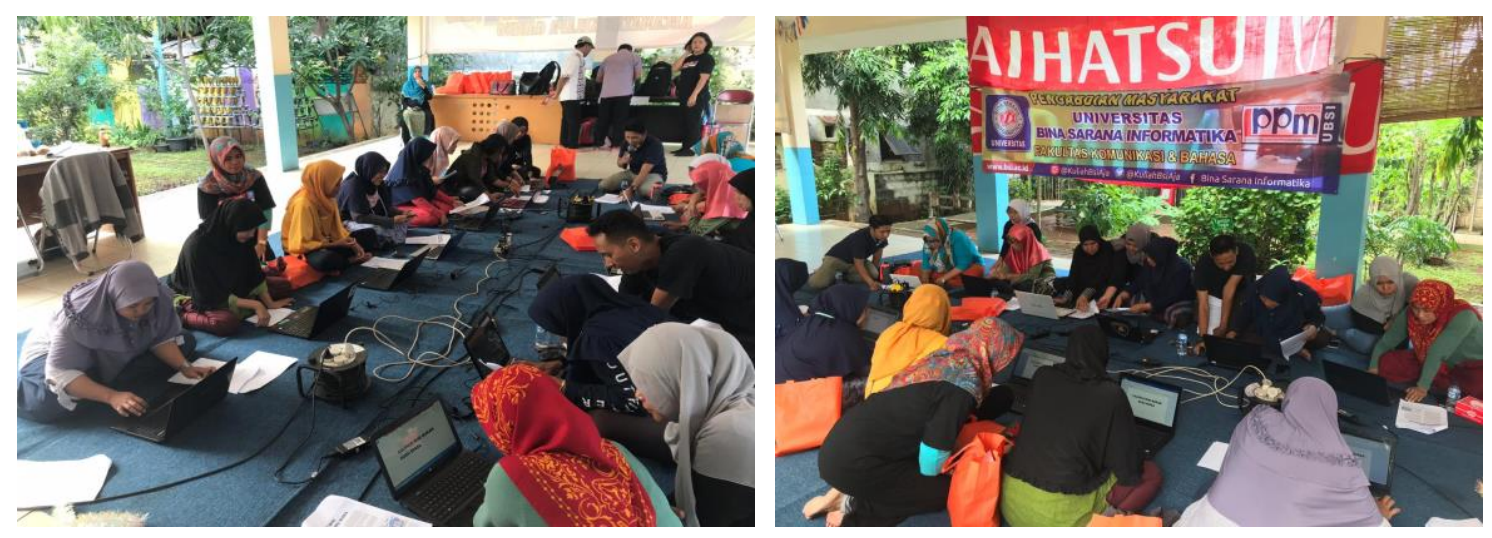

Gambar 2. Para tutor membimbing peserta dalam menulis advertorial 
Jurnal Pengabdian Kepada Masyarakat

Selama sesi Praktek berlangsung, para peserta melakukan penulisan secara santai dan leluasa, serta tanpa sungkan meminta bantuan para tutor yang dengan sabar membimbing dari awal hingga akhir kegiatan. Semua pihak yang terlibat bekerjasama dengan sangat baik dan tercipta suasana yang menyenangkan, penuh kekeluargaan.

\section{Evaluasi}

Setelah kegiatan Pengabdian Masyarakat (PM) selesai dilaksanakan, selanjutnya pihak penyelenggara melakukan evaluasi secara menyeluruh, baik terhadap proses awal (perencanaan), saat pelaksanaan pelatihan atau praktek, maupun terhadap hasil pelatihan itu sendiri. Tujuan evaluasi adalah untuk mengetahui apakah perencanaan yang dibuat sudah lengkap, apakah kegiatan terlaksana sesuai perencanaan, apakah hasil yang diperoleh sesuai yang diharapkan, apa saja hambatan atau kesulitan yang dihadapi, dan unsur apa saja yang dapat dikembangkan atau ditambahkan agar kegiatan yang akan datang dapat terselenggara dengan lebih sukses dan mendatangkan lebih banyak manfaat bagi para peserta.

Secara garis besar, hasil evalusi menunjukan bahwa kegiatan pelatihan penulisan advertorial menggunakan Microsoft Word berlangsung lancar sesuai rencana. Para peserta akhirnya dapat mengenal tools yang terdapat dalam komputer, sehingga nantinya akan memudahkan dan memperlancar dalam penulisan berbagai informasi yang akan dimuat di papan pengumuman di lingkungan RW 02 Pegangsaan Dua, Jakarta Utara. Penyampaian informasi itupun kini lebih bervariasi karena ditulis secara lebih kreatif, yaitu dengan menggabungkan antara naskah dan gambar. Hal ini berimbas positif, warga menjadi lebih tertarik dan terdorong untuk mengetahui serta membaca isi papan pengumuman. Selain itu, ketrampilan penulisan ini juga dirasakan sangat bermanfaat dan mempermudah mereka dalam membuat surat menyurat untuk keperluan kegiatan PKK.

Di sisi lain, bagi peserta yang memiliki usaha atau bisnis, baik dalam skala kecil maupun menengah, ketrampilan menulis advertorial dapat diterapkan dalam pembuatan promosi produk-produk yang mereka jual. Sebelum mengikuti pelatihan, para ibu pengusaha ini hanya membuat tulisan sederhana yang berisi informasi mengenai jenis-jenis produk yang dijual atau menawarkan secara langsung produk-produk tersebut kepada orang lain. Mereka juga terkadang mengalami kesulitan dalam menjelaskan secara detail manfaat penggunaan produk, serta apa saja kelebihan-kelebihan produk itu jika dibandingkan produk lain yang sejenis. Namun kini, para peserta dapat menulis pesan promosi secara lebih kreatif dengan menggunakan komputer dan memanfaatkan tools yang tersedia.

Hasil evaluasi kegiatan PM di RPTRA H.Ohyar, Pegangsaan Dua, Jakarta Utara pada dasarnya menyimpulkan, bahwa kegiatan pelatihan bagi warga di lingkungan tersebut sangat diperlukan dan dinantikan, apalagi pelatihan ini diberikan secara gratis, tidak memungut biaya apapun dari para pesertanya. Di masa mendatang, para peserta dan pengelola RPTRA berharap agar kegiatan pelatihan seperti ini akan terus dilakukan secara rutin dan berkesinambungan dengan materi pelatihan yang disesuaikan menurut kebutuhan masyarakat sekitar. Durasi pelatihan juga diharapkan dapat diperpanjang, sehingga para peserta dapat mempelajari dan 
memahami materi secara lebih mendalam dan melakukan praktek dengan lebih tenang, tidak terburu-buru.

\section{Simpulan dan Rekomendasi}

Pengabdian Masyarakat yang dilaksanakan di RPTRA H. Ohyar, Pegangsaan Dua, Jakarta Utara telah berlangsung lancar dan membawa banyak manfaat bagi para warga di lingkungan tersebut. Tingginya antusias ibu-ibu PKK yang mengikuti kegiatan pelatihan menunjukan, bahwa pelatihan penulisan yang diberikan merupakan kegiatan yang penting, yang mereka butuhkan untuk menjawab masalah yang dihadapi, seperti membuat tulisan-tulisan yang berisi informasi penting di papan pengumuman dan surat menyurat untuk kebutuhan kedinasan. Selain itu, ketrampilan penulisan ini juga sangat bermanfaat bagi para peserta yang memiliki usaha atau bisnis karena dapat membuat pesan promosi yang tidak hanya persuasif, namun juga lebih kreatif, menarik, dan informatif.

Penulisan advertorial yang kreatif membutuhkan ketrampilan tersendiri, baik dalam pemilihan dan penyusunan kata-kata, penentuan gambar yang sesuai, maupun pengaturan layout yang tepat. Semua itu dapat dikuasai melalui suatu proses, tidak muncul secara tiba-tiba. Strategi kreatif harus dirumuskan dan diterapkan agar inti pesan yang dimuat dalam advertorial dapat diterima dengan baik oleh khalayak. Proses belajar dan strategi kreatif ini menjadi faktor pendukung yang kuat, yang sangat berpengaruh terhadap kesuksesan penyampaian isi pesan, baik yang bersifat informatif maupun persuasif. Faktor penghambat yang dialami dalam kegiatan pelatihan penulisan advertorial, antara lain fasilitas komputer yang sangat sedikit, waktu pelatihan yang sangat singkat dengan frekwensi pertemuan yang hanya satu kali, serta kondisi daya ingat para peserta yang sudah menurun karena rata-rata usia di atas 50 tahun.

Rekomendasi yang dapat diberikan bagi kesuksesan pelaksanaan kegiatan PM berikutnya adalah dilakukannya peningkatan sarana dan prasarana yang dibutuhkan agar memudahkan para peserta dalam menjalani proses pembelajaran dan mengaplikasikan apa yang telah didapatkan dari proses pelatihan. Pengelola RPTRA H. Ohyar sebaiknya mengingatkan ibu-ibu PKK yang telah mengikuti pelatihan penulisan supaya terus melakukan latihan/praktek penulisan dengan menggunakan komputer untuk meningkatkan kemampuan dan mengingat terus materi yang telah dipelajari, dan selanjutnya menerapkan dalam kehidupan seharihari, baik dalam urusan kedinasan maupun dalam mengelola usaha, khususnya dalam melakukan promosi

\section{Daftar Pustaka}

Maulina Rishna. (2019). Iklan Advertorial Sebagai Stategi Pemasaran Terbaik. Retrieved June 25, 2019, from https:/ / www.jurnal.id/id/blog/iklan- 
Jurnal Pengabdian Kepada Masyarakat

advertorial-sebagai-stategi-pemasaran-terbaik/

Negara, A. S. (2016). Perbandingan Pengaruh Advertorial dan Iklan Majalah dalam Mereposisi Citra Merek Sehingga Terciptanya WOM. Universitas Islam Indonesia. Retrieved from https://studylibid.com/doc/1047578/perbandingan-pengaruhadvertorial-dan-iklan-majalah

Partawan, Km. Sugi, I. B. Putrayasa, S. A. P. S. (2014). Penggunaan Advertorial di TV Untuk Meningkatkan Kemampuan Menulis Paragraf Persuasi Siswa Kelas X UPW di SMK Negeri 2 Bangli. 8. Jurnal Undiksha. Retrieved from https://ejournal.undiksha.ac.id/index.php/JJPBS/article/download/2457/212 3

Primadini, I. (2016). Pengaruh Advertorial Mengenai CSR Dalam Pembentukan Citra Merek :Studi Pada Advertorial “Lifebuoy Berbagi Sehat” Di Harian Kompas. Jurnal ULTIMACOMM, Vol.8(No.2, 59).

Sugihantoro. (2010). Modul Pengantar Periklanan. Medan: Pusat Pengembangan Bahan Ajar UMB.

Warni, S. (2015). Mengenal Konsep Iklan Advertorial. Retrieved June 25, 2019, from https://zahiraccounting.com/id/blog/mengenal-konsep-iklan-advertorial/ 